\title{
Kelayakan Finansial Usahatani Buah Naga Di Daerah Perkotaan Sebagai Alternatif Tambahan Pendapatan Petani
}

\author{
IDA AYU LISTIA DEWI DAN I NYOMAN GEDE USTRIYANA \\ Program Studi Agribisnis Fakultas Pertanian Universitas Udayana \\ Jalan P.B. Sudirman Denpasar 80232 \\ Email: listiadewi60@yahoo.co.id
}

\begin{abstract}
Financial Feasibility Of Dragon Fruits Farming In Urban Area As Additional Alternatives Of Farmer's Revenues
\end{abstract}

This study aims to analyze the financial feasibility of Dragon Fruit Farming in urban areas. Analyze the sensitivity of Dragon Fruit farming on the changes of production quantity, product selling price, and production cost. The pilot unit of Dragon Fruit Farming in urban area is in Experiment Garden of Faculty of Agriculture Udayana University. Key informants of this research are garden managers, field officers, field workers in Experimental Garden of Faculty of Agriculture Udayana University. The data used are Bank Rakyat Indonesia's interest rate, investment cost (seedling cuttings, climbers, used tires, rope, and equipment), operational cost (fertilizer and labor), production quantity, and product selling price. Data analysis used analysis of investment criteria and business sensitivity analysis. The results showed that the Dragon Fruit Farming in Experimental Garden of Faculty of Agriculture Udayana University was profitable so it was feasible to run. The value of farm income is Rp $231,453,087$, Net B / C value is 4.03 . IRR> I is $49.63 \%>18 \%$, the rate of payback for five years is eight months. This effort is very sensitive to the $50 \%$ decline in the selling price.

Keywords: financial, investment, sensitivity

\section{Pendahuluan}

\subsection{Latar Belakang}

Daerah perkotaan merupakan pusat pembangunan baik dalam bidang ekonomi, pendidikan, teknologi, dan kesehatan. Dibangunnya sarana dan prasarana penunjang perkembangan pembangunan daerah perkotaan sering mengorbankan lahan pertanian. Sehingga ketersediaan lahan pertanian di perkotan menjadi sedikit. Denpasar merupakan ibukota Provinsi Bali juga memiliki keterbatasan ketersediaan lahan pertanian. Namun demikian Kota Denpasar harus mampu memenuhi kebutuhan pangan masyarakatnya. 
Kebun Percobaan Fakultas Pertanian Unud yang terletak di Kota Denpasar merupakan suatu percontahan pengelolaan kegiatan usahatani di daerah perkotaan. Bagaimana mengelola kegiatan usahatani di perkotaan menjadi suatu unit bisnis yang menguntungkan. Berdasarkan hasil pengelolaan unit bisnis di Kebun Percobaan Fakultas Pertanian, petani di Kota Denpasar dapat mengikuti pola pengelolaan tersebut. Salah satu usaha yang diharapkan menjadi unit bisnis adalah usahatani tahunan yaitu Buah Naga. Produk Buah Naga dipilih, karena belakangan ini masyarakat mulai menyukainya. Buah Naga dipilih untuk dikembangkan di Kota Denpasar karena topografi lahan dan agroklimatnya mendukung.

Membangun unit usaha tentunya membutuhkan modal yang tidak sedikit, oleh sebab itu perlu diperhitungkan investasi yang dikorbankan untuk memperoleh keuntungan. Investasi dapat pula diartikan penanaman modal dalam suatu kegiatan yang memiliki jangka waktu relatif panjang dalam berbagai bidang usaha yang mana dalam arti sempit berupa proyek tertentu baik bersifat fisik dan nonfisik (Kasmir dan Jakfar, 2009). Menurut Gittingger (1986), kegiatan investasi dapat merubah sumber finansial menjadi barang kapital yang dapat menghasilkan keuntungan atau manfaat setelah beberapa periode waktu. Bila suatu investasi tidak diperhitungkan secara finansial maka modal besar yang tertanam sebagai investasi tidak akan kembali. Menurut Umar (2007) menganalisis aspek keuangan atau finansial dari suatu studi kelayakan bisnis bertujuan untuk menentukan rencana investasi melalui perhitungan biaya dan manfaat yang diharapkan, dengan membandingkan antara pengeluaran dan pendapatan, seperti ketersediaan dana, biaya modal, kemampuan proyek untuk membayar kembali dana tersebut dalam waktu yang telah ditentukan dan menilai apakah proyek akan dapat berkembang.

Mengingat umur investasi sangat lama sampai dengan 15 tahun, maka akan mungkin terjadi banyak perubahan-perubahan baik faktor teknis, sosial ekonomi, dan lainnya. Menurut Gittinger (1986) suatu proyek pada dasarnya menghadapi ketidakpastian karena dipengaruhi perubahan-perubahan, baik dari sisi pengeluaran yang akhirnya akan mempengaruhi tingkat kelayakan suatu proyek. Sehubungan dengan hal tersebut, maka dirasakan perlu untuk dilakukan sebuah analisis atau penelaahan kembali terhadap suatu proyek untuk melihat pengaruh-pengaruh yang terjadi akibat adanya perubahan-perubahan. Oleh sebab itu perlu dilihat seberapa besar pengaruh perubahan tersebut bagi keberlanjutan usaha Buah Naga dengan mengevaluasi sensitifitas usaha.

Berdasarkan uraian latar belakang di atas maka dianggap perlu melakukan suatu kajian tentang kelayakan finansial usahatani Buah Naga di daerah perkotaan yaitu di Kebun Percobaan Fakultas Pertanian Universitas Udayana. Hasil kajian ini dapat dipergunakan sebagai pertimbangan bagi petani di Kota Denpasar untuk melakukan budidaya Buah Naga Merah di lahan garapannya. 


\subsection{Tujuan Penelitian}

Sejalan dengan permasalahan yang telah dirumuskan, maka tujuan dari penelitian ini untuk: (1) menganalisa kelayakan finansial usahatani Buah Naga di daerah perkotaan yaitu di Kebun Percobaan Fakultas Pertanian Universitas Udayana; (2) untuk menganalisis sensitifitas usahatani Buah Naga Merah di Kebun Percobaan Fakultas pertanian Universitas Udayana terhadap perubahan kuantitas produksi, harga jual produk, dan biaya produksi.

\section{Metode Penelitian}

\subsection{Lokasi dan Waktu Penelitian}

Penelitian ini akan dilakukan di Kebun Percobaan Fakultas Pertanian Universitas Udayana, yang terletak Desa Pedungan, Denpasar Selatan. Pemilihan lokasi ditentukan dengan Metode Purposive yaitu pemilihan lokasi secara sengaja berdasarkan pertimbangan adanya pembukaan unit bisnis yang membutuhkan investasi besar di lokasi penelitian pada awal tahun 2016.

\subsection{Penentuan Populasi dan Responden}

Penelitian ini mempergunakan informan kunci untuk menggali informasi lebih dalam mengenai data penelitian. Penentuan informan kunci ditentukan secara purposive, yaitu secara sengaja berdasarkan pertimbangan mereka yang mengetahui dan ikut berkecimpung dalam unit bisnis Buah Naga di Kebun Percobaan Fakultas Pertanian Universitas Udayana yaitu sebagai berikut.

1. Ketua pengelola kebun sebagai kepala penanggungjawab kegiatan kebun.

2. Sekretaris pengelola kebun sebagai penanggungjawab kegiatan kebun.

3. Bendahara pengelola kebun sebagai pengelola keuangan kebun termasuk unit bisnis.

4. Penanggungjawab lapangan yaitu seksi produksi proyek unit bisnis Buah Naga.

5. Para tenaga kerja lapangan sebanyak tiga (3) orang, sebagai pelaksana lapangan pada usaha Buah Naga.

\subsection{Metode Pengumpulan Data, Instrumen Pengumpulan Data, dan Metode Analisis}

Metode pengumpulan data yang akan dilakukan dengan menggunakan beberapa metode berikut ini.

1. Wawancara, yaitu dengan melakukan tanya jawab dengan responden yang terlibat dalam objek penelitian dengan instrumen daftar pertanyaan.

2. Studi dokumentasi, yaitu pengumpulan data dengan cara melihat dan mencatat dokumen atau catatan yang berhubungan dengan penelitian sebagai data penunjang.

3. Studi kepustakaan, yaitu metode yang digunakan dalam mencari teori-teori dan pengertian melalui buku-buku, literatur, dan media elektronik lainnya yang berkaitan dengan pokok pembahasan. Instrumen pengumpulan data yang 
dipergunakan adalah kuesioner. Menurut Nurmalina, dkk (2009), menilai tentang baik tidaknya atau layak tidaknya suatu bisnis diperlukan pengukuran menggunakan kriteria investasi. Berdasarkan hal tesebut Analisis data yang dipergunakan untuk menjawab tujuan penelitian pertama yaitu mengetahui analisis finansial buah naga pada Kebun Percobaan Fakultas Pertanian Unud dianalisis dengan analisis deskriptif kuantitatif dengan pendekatan kriteria investasi yaitu NPV, Net B/C, IRR, dan Payback Periode. Tujuan penelitian kedua yaitu untuk mengetahui sensitivitas usahatani buah naga dengan menggunakan analisis deskriptif kuantitatif, dengan beberapa asumsi yang digunakan yaitu penurunan kuantitas produksi karena perubahan cuaca atau serangan penyakit sebesar 30\%, kenaikan biaya produksi akibat perubahan harga input sebesar $20 \%$, dan penurunan harga jual akibat musim panen raya sebesar $50 \%$.

\section{Hasil dan Pembahasan}

\subsection{Kelayakan Finansial Usahatani Buah Naga di Kebun Percobaan Fakultas Pertanian Universitas Udayana}

Penelitian ini adalah penelitian deskriptif kuantitatif yang menggambarkan kondisi kelayakan usahatani tanaman Buah Naga di Kebun Percobaan Fakultas Pertanian Universitas Udayana. Kelayakan usahatani Buah Naga yang dianalisis dibatasi hanya melihat kelayakan secara finansialnya. Adapun asumsi-asumsi yang akan dipergunakan sebagai dasar perhitungan dalam analisis financial pada usaha buah Naga Merah di Kebun Percobaan Fakultas Pertanian Unud adalah sebagai berikut.

1. Umur ekonomis unit bisnis Buah Naga Merah adalah 15 tahun. Penentuan umur ekonomis 15 tahun sama dengan penelitian Tias (2015) dan Destiarni (2013). Pencatatan mulai dilakukan dari tahun 2016 sampai dengan tahun 2031.

2. Umur tanaman saat ini semuanya sama yaitu nol tahun.

3. Tahun pertama adalah tahun investasi yang terdiri dari pengolahan lahan, pembuatan tiang panjatan, pemupukan, penanaman, dan pembelian peralatan modal.

4. Reinvestasi dilakukan untuk pembelian peralatan yang umur ekonomisnya pendek, dan kegiatan reinvestasi dilakukan sampai akhir umur ekonomis unit usaha Buah Naga merah. Nilai reinvestasi diasumsikan sama nilai investasi awal.

5. Harga input produksi diasumsikan sama sampai umur ekonomis unit bisnis berakhir.

6. Harga jual produk diasumsikan sama sampai dengan akhir umur ekonomis unit bisnis Buah Naga Merah.

7. Penjualan produk diasumsikan dilakukan pada tahun ke tiga, yaitu setelah dua tahun penanaman yaitu tahun 2018 .

8. Tingkat suku bunga (discout rate) yang dipergunakan adalah berdasarkan besarnya bunga pada bank komersial di daerah Denpasar yaitu 18\% per tahun. 
Analisis finansial diawali dengan menghitung analisis biaya, penerimaan, analisis kreteria investasi, dan sensitifitas. Masing-masing analisis tersebut akan dibahas pada bagian tersendiri.

\subsubsection{Analisis biaya}

Biaya secara keseluruhan dikelompokkan menjadi biaya investasi dan biaya operasional. Biaya investasi adalah biaya yang dikeluarkan diawal proyek/usaha dan dibeli kembali diakhir umur ekonomisnya. Sedangkan biaya operasional adalah biaya yang dikeluarkan selama usahatani berlangsung yaitu dari tahun pertama sampai tahun ke-lima belas. Adapun besarnya nilai biaya investasi, biaya operasional, dan total biaya dapat dilihat pada tabel berikut.

Tabel 1.

Biaya Investasi dan Biaya Operasional dalam Usahatani Buah Naga di Kebun Percobaan Fakultas Pertanian

\begin{tabular}{cccc}
\hline Tahun & Biaya Investasi & Biaya Operasional & Total Biaya \\
\hline 1 & $3,095,000$ & $48,415,000$ & $51,510,000$ \\
2 & 0 & $48,201,500$ & $48,201,500$ \\
3 & 90,000 & $50,863,900$ & $50,953,900$ \\
4 & 625,000 & $55,785,790$ & $56,410,790$ \\
5 & 90,000 & $59,056,994$ & $59,146,994$ \\
6 & $1,950,000$ & $63,350,068$ & $65,300,068$ \\
7 & 715,000 & $68,575,575$ & $69,290,575$ \\
8 & 0 & $72,976,133$ & $72,976,133$ \\
9 & 90,000 & $77,746,746$ & $77,836,746$ \\
10 & 625,000 & $83,071,421$ & $83,696,421$ \\
11 & $2,470,000$ & $70,027,137$ & $72,497,137$ \\
12 & 0 & $59,798,209$ & $59,798,209$ \\
13 & 715,000 & $47,292,496$ & $48,007,496$ \\
14 & 0 & $39,315,498$ & $39,315,498$ \\
15 & 0 & $31,355,799$ & $31,355,799$ \\
\hline
\end{tabular}

Berdasarkan tabel di atas dapat diketahui bahwa biaya investasi dari tahun ke tahun tidak sama, ini disebabkan karena waktu ekonomis peralatan tidak sama, sehingga waktu reinvestasi menjadi berbeda-beda. Investasi di tahun awal merupakan nilai paling besar karena semua peralatan dibeli di tahun awal. Pada biaya produksi ada biaya yang bersifat sebagai biaya variabel yaitu biaya pupuk kompos, sekam, pupuk kandang, dan tenaga kerja. Dan opportunity cost (biaya atas kesempatan yang hilang yaitu penjualan panen padi secara tebasan selama tiga musim tanam) merupakan biaya yang bersifat tetap. Penggunaan pupuk kompos dan sekam hanya pada tahun pertama, tepatnya pada saat membuat media tanam Buah Naga. Pupuk Kandang selalu dipergunakan sampai akhir masa ekonomis usahatani, dan penggunaannya diprediksi secara konsep teoritis. Dilihat secara total biaya yang paling tinggi ada pada tahun ke-10 yaitu sebesar Rp 83,696,421. Ini disebabkan 
karena secara konsep tahun ke-10 adalah tahun maksimum produksi, sehingga semakin banyak produksi yang dihasilkan semakin banyak pula kebutuhan bubuk kandang bagi tanaman Buah Naga.

\subsubsection{Penerimaan Buah Naga Merah}

Pemerimaan dalam penelitian ini adalah hasil penjualan produksi dikalikan dengan harga buah naga per kg dari tahun ke-2 sampai ke-15. Diasumsikan semua hasil terjual. Buah Naga mulai berproduksi di tahun ke-2, secara teoritis hasil panen pertama dan kedua adalah massa belajar berproduksi sehingga hasilnya belum optimal, oleh sebab itu harganya pun lebih rendah dari hasil umumnya. Secara lengkap perkiraan penerimaan dapat dilihat dari tabel berikut.

Tabel 2.

Perkiraan Penerimaan Usahatani Buah Naga di Kebun Percobaan Fakultas Pertanian Unud

\begin{tabular}{cccc}
\hline Tahun & Produksi $(\mathbf{k g})$ & Harga/kg $(\mathbf{R p})$ & Penerimaan $(\mathbf{R p )}$ \\
\hline 1 & 0 & 0 & 0 \\
2 & 1,296 & 10,000 & $12,960,000$ \\
3 & 3,888 & 10,000 & $38,880,000$ \\
4 & 5,184 & 15,000 & $77,760,000$ \\
5 & 9,720 & 15,000 & $145,800,000$ \\
6 & 11,664 & 15,000 & $174,960,000$ \\
7 & 15,552 & 15,000 & $233,280,000$ \\
8 & 18,144 & 15,000 & $272,160,000$ \\
9 & 18,144 & 15,000 & $272,160,000$ \\
10 & 18,144 & 15,000 & $272,160,000$ \\
11 & 10,368 & 15,000 & $155,520,000$ \\
12 & 8,640 & 15,000 & $129,600,000$ \\
13 & 6,480 & 15,000 & $97,200,000$ \\
14 & 5,184 & 15,000 & $77,760,000$ \\
15 & 3,240 & 15,000 & $48,600,000$ \\
\hline
\end{tabular}

Berdasarkan tabel di atas dapat dilihat penerimaan meningkat dari tahun ke-3 sampai tahun ke-8, kemudian tetap sampai tahun ke-10, kemudian tahun ke-11 menurun. Hal ini sesuai dengan siklus produksi dari buah naga. Menurut Rahayu (2014), produksi pertama tanaman buah naga menghasilkan tiga sulur dengan masing-masing sulur menghasilkan tiga buah naga. Produksi kedua jumlah sulur produktif menjadi Sembilan. Produksi tahun ketiga dan empat jumlah sulur sudah menjadi 12. Dipadukan dengan hasil penelitian Khairunnas dan Ermi (2011) bahwa total produksi total produksi Buah Naga mengalami peningkatan mulai dari produksi pertama sampai tahun produksi keenam, sedangkan dari tahun ketujuh sampai tahun ke sepuluh produksi Buah Naga mencapai titik maksimum. Total produksi ditahun ke 11 sampai tahun selanjutnya, mengalami penurunan, karena disebabkan umur siklus produksi mulai menurun. Berdasarkan kedua sumber tersebut maka diprediksi 
jumlah produksi Buah Naga di Kebun Percobaan sesuai dengan Tabel 3, dimana masing-masing tiang penyangga berisi tiga batang stek. Sehingga nilai produksi tertinggi sebesar Rp 272,160,000, yaitu pada tahun ke delapan, Sembilan, dan sepuluh.

\subsubsection{Analisis kreteria investasi}

Investasi pada usahatani Buah Naga di Kebun Percobaan FP Unud akan menguntungkan atau tidak dilakukan analisis kreteria investasi dengan menghitung nilai NPV, Net B/C, IRR, dan Payback Periode usaha ini pada tingkat suku bunga (i) sebesar $18 \%$. Nilai suku bunga yang dipergunakan adalah suku bunga kredit Bank Rakyat Indonesia tahun 2016. Nilai kreteria investasi pada usahatani buah naga di Kebun Percobaan dapat dilihat pada tabel berikut.

\section{Tabel 3.}

Hasil Analisis Kreteria Investasi Buah Naga di Kebun Percobaan Fakultas Pertanian Unud

\begin{tabular}{clc}
\hline No & \multicolumn{1}{c}{ Uraian } & Nilai \\
\hline 1 & NPV & Rp 231.453.087 \\
2 & Net B/C & 4,03 \\
3 & IRR & $49.63 \%$ \\
4 & Payback Periode & 5 tahun, 8 bulan \\
\hline
\end{tabular}

Nilai NPV sebesar Rp 231,453,087. Ini berarti prediksi keuntungan yang diperoleh dari usahatani Buah Naga di Kebun Percobaan Fakultas Pertanian selama 15 tahun sebesar Rp 231,453,087. Kondisi ini menunjukkan bahwa usaha ini menguntungkan. Bila dibandingkan dengan nilai NPV pada penelitian Khairunnas dan Ermi (2011) sebesar Rp 2,863,335,982.09. Nilai ini jauh berbeda karena pada penelitian Khairunnas dan Ermi jumlah tiang panjatan sejumlah 1600 tiang (satu hektar) dengan masing-masing tiang berisi empat bibit stek. Sedangkan di Kebun Percobaan Fakultas Pertanian Unud hanya terdapat 240 batang panjatan (setara tujuh are) dimana masing-masing tiang panjatan hanya terdiri dari tiga bibit stek. Menurut informan kunci, masing-masing tiang panjatan berisi tiga bibit stek karena keterbatasan modal yang dimiliki dan kurangnya keberadaan bibit saat itu.

Nilai Net B/C dari usahatani Buah Naga di Kebun Percobaan Fakultas Pertanian adalah sebesar 4,03. Nilai ini berarti bahwa setiap Rp 1 biaya yang dikeluatkan dalam usahatani buah naga akan mengkasilkan pendapatan usahatani sebesar Rp 4,04. Ini juga menggambarkan perolehan empat kali lipat benefit dari setiap biaya yang di keluarkan. Maka berdasarkan nilai tersebut maka usahatani Buah Naga di Kebun Percobaan Fakultas Pertanian layak diusahakan.

Nilai IRR dari usahatani Buah Naga di Kebun Percobaan Fakultas Pertanian Unud sebesar 49,63\%. Tujuan perhitungan IRR adalah untuk menunjukkan kemampuan bisnis dalam mengembalikan bunga pinjaman. Sehingga dari nilai IRR yang diperoleh yaitu sebesar 49,63\% lebih besar dari tingkat suku bunga kredit di 
Bank Rakyat Indonedia yaitu 18\%, ini menunjukkan tingkat suku bunga yang diperoleh pada nilai NPV nol/ penerimaan nol adalah 49,63\% mampu menutupi bunga kredit pinjaman pada Bank Rakyat Indonesia yang hanya sebesar $18 \%$. Kondisi ini menunjukkan bahwa usahatani Buah Naga tersebut layak dilaksanakan.

Nilai Payback Periode sebesar lima tahun delapan bulan. Artinya nilai modal yang diinvestasikan oleh pengelola untuk usahatani Buah Naga di Kebun Percobaan Fakultas Pertanian Unud mampu tertutupi dalam waktu lima tahun delapan bulan. Berdasarkan analisis kreteria investasi yaitu NPV, Net B/C, IRR, dan Payback Periode diperoleh kesimpulan usahatani Buah Naga tersebut layak diusahakan.

\subsection{Sensitifitas Usahatani Buah Naga Merah Di Kebun Percobaan Fakultas Pertanian Universitas Udayana}

Analisis sensitivitas digunakan untuk mengetahui perubahan-perubahan kriteria kelayakan usahatani buah naga akibat kemungkinan perubahan situasi, mengingat berinvestasi di sektor pertanian penuh dengan resiko. Kadariah (1999) mengungkapkan bahwa Sensitivity analisis bertujuan untuk melihat apa yang akan terjadi dengan hasil analisis proyek jika ada suatu kesalahan atau perubahan dalam dasar-dasar perhitungan biaya/benefit. Pada bidang pertanian proyek sensitif berubah-ubah akibat masalah utama, antara lain harga, keterlambatan pelaksanaan, kenaikan biaya, dan hasil. Berdasarkan perubahan kondisi tersebut maka ada beberapa asumsi yang digunakan dalam penelitian ini. Adapun asumsi yang digunakan adalah sebagai berikut.

a. Penurunan kuantitas produksi karena perubahan cuaca atau serangan penyakit, sebesar $30 \%$.

b. Kenaikan biaya produksi akibat perubahan harga input, sebesar $20 \%$.

c. Penurunan harga jual akibat musim panen raya, sebesar $50 \%$.

Pada tabel berikut akan dijabarkan hasil perhitungan perubahan masing-masing nilai kreteria investasi akibat adanya perubahan situasi di atas.

Tabel 4.

Hasil Perhitungan Analisis Sensitifitas Usahatani Buah Naga di Kebun Percobaan Fakultas Pertanian Unud

\begin{tabular}{ccccccc}
\hline No & \multicolumn{1}{c}{$\begin{array}{c}\text { Kondisi } \\
\text { Perubahan }\end{array}$} & NPV & $\begin{array}{l}\text { Net } \\
\text { B/C }\end{array}$ & IRR & $\begin{array}{l}\text { Payback } \\
\text { Periode }\end{array}$ & Kesimpulan \\
\hline 1 & $\begin{array}{l}\text { Penurunan } \\
\text { produksi 30\% }\end{array}$ & 73.473 .733 & 1,8 & $30,40 \%$ & 7 th, 7 bln & Layak \\
2 & $\begin{array}{l}\text { Peningkatan } \\
\text { Biaya Produksi }\end{array}$ & 172.424 .135 & 2,76 & $39,71 \%$ & 6 th, 6 bln & Layak \\
& $\begin{array}{l}20 \% \\
\text { Penurunan } \\
\text { harga jual 50\% }\end{array}$ & -31.845 .837 & 0,69 & - & - & Tidak \\
& & & & & Layak \\
\hline
\end{tabular}

Berdasarkan tabel di atas maka usahatani Buah Naga di Kebun Percobaan Fakultas Pertanian Universitas Udayana dapat dikatakan unit bisnis ini sangat sensitif 
terhadap perubahan harga, tepatnya penurunan harga jual sebesar 50\%. Akibat penurunan harga jual 50\% prediksi penerimaan yang diperoleh dari usahatani Buah Naga di Kebun Percobaan Fakultas Pertanian setelah terjadi penurunan harga jual $50 \%$ mengalami kerugian sebesar $\mathrm{Rp} 31,845,837$. Kondisi ini sama dengan penelitian Destiarni (2013) sensitif terhadap terjadinya penurunan harga output sebesar 23\%. Ini menandakan usahatani buah naga sangat sensitif terhadap perubahan harga, tentunya perubahan harga dimasing-masing daerah berbeda-beda. Harga yang dipergunakan dalam penelitian ini adalah harga yang diperoleh petani Buah Naga Merah di Badung Utara, salah satu sentra produksi Buah Naga Merah yang lokasinya paling dekat dengan kota Denpasar, dibandingkan sentra-sentra lainnya. Sehingga penurunan harga $50 \%$ juga berdasarkan pengalaman yang terjadi di tingkat petani Buah Naga Merah di Badung Utara. Hal ini sesuai dengan pendapat Soekartawi (1991) bahwa analisis finansial dilakukan pada keadaan sebenarnya dengan menggunakan data harga yang sebenarnya ditemukan di lapangan, sehingga dapat disesuaikan bila proyek tersebut menyimpang dari rencana semula.

\section{Simpuan dan Saran}

\subsection{Simpulan}

Berdasarkan hasil penelitian dapat disimpulkan sebagai berikut.

1. Berdasarkan analisis kreteria investasi disimpulkan bahwa Usahatani Buah Naga di Kebun Percobaan Fakultas Pertanian Unud menguntungkan sehingga layak untuk dijalankan nilai NPV sebesar Rp 231,453,087.

2. Berdasarkan analisis sensitifitas usahatani Buah Naga di Kebun Percobaan Fakultas Pertanian Unud sangat sensitif terhadap penurunan harga jual Buah Naga yaitu sebesar $50 \%$.

\subsection{Saran}

Beradarkan kesimpulan di atas maka, ada beberapa saran yang diberikan. Bagi petani di Kota Denpasar yang tertarik berinvestasi usahatani Buah naga Merah sebaiknya melakukan penanaman bibit Buah Naga di awal proyek sebanyak empat bibit dalam satu tiang tanam untuk menghasilkan produksi yang lebih banyak. Menindaklanjuti sensitifitas usaha ini pada penurunan harga, maka perlu dilakukan kajian kelayakan pasar untuk bisa menentukan harga keseimbangan yang terbentuk dan juga melihat elastisitas harga tersebut terhadap perubahan-perubahan.

\section{Ucapan Terima Kasih}

Penulis menyampaikan terima kasih kepada Rektor Universitas Udayana selaku pemberi dana melalui Wakil Dekan II Fakultas Pertanian dan juga Lembaga Penelitian dan Pengabdian kepada Masyarakat Universitas Udayana sebagai penyelenggara administrasi. 


\section{Daftar Pustaka}

Destiarni, Resti R. 2013. Analisis Kelayakan Pengembangan Usaha Budidaya Buah naga (Hylocereus sp.) Di Desa Rombasan Kecamatan Pragaan Kabupaten Sumenep Jawa Timur. Skripsi. Institut Pertanian Bogor, Fakultas Ekonomi dan Manajemen, Departemen Agribisnis. Bogor.

Gittinger, JP. 1986. Analisa Ekonomi Proyek-Proyek Pertanian. UI Press. Jakarta. Kadariyah. 1999. Pengantar Evaluasi Proyek. Jakarta: LPFE Universitas Indonesia. Kasmir dan Jakfar. 2009. Studi Kelayakan Bisnis. Penerbit: Kencana. Jakarta.

Khairunnas, dan Ermy T. 2011. ANALISIS KELAYAKAN USAHATANI BUAH NAGA (HYLOCEREUS COSTARICANSIS) DI PEKANBARU (Studi di Kelurahan Sail Tenayan Raya Pekanbaru). Pekbis Jurnal. Vol: 3, No: 3. ISSN: 579-585. Hal 579-585

Nurmalina R, Sarianti T, Karyadi A. 2009. Studi Kelayakan Bisnis. Departemen Agribisnis Fakultas Ekonomi dan Manajemen Institut Pertanian Bogor. Bogor.

Rahayu, Sri. 2014. Budidaya Buah Naga Cepat Panen. Penerbit: Infra Hijau. Bogor.

Soekartawi.1991. Agribisnis: Teori dan Aplikasi. Jakarta: Raja Grafindo Persada.

Tias, Ayuning. 2015. Analisis Finansial Usahatani Buah Naga Super Merah (Hylocereus costaricensis) (Studi Kasus pada Kelompok Tani Berkah Naga di Desa Sambirejo, Kecamatan Bangorejo, Kabupaten Banyuwangi). Skripsi. Universitas Udayana, Program Ekstensi Fakultas Pertanian. Program Studi Agribisnis. Denpasar.

Umar H. 2007. Studi Kelayakan Bisnis Teknik Menganalisis Kelayakan Rencana Bisnis Secara Komprehensif. Penerbit:PT. Gramedia Pustaka Utama. Jakarta. 